\title{
Selecting Usability Heuristics to Evaluate Responsive Maps: Case Study WebGIS UFPR CampusMap
}

\author{
Vinícius Emmel Martins a , Marcio Augusto Reolon Schmidt a,b, Luciene Stamato Delazari a \\ ${ }^{a}$ Programa de Pós-Graduação em Ciências Geodésicas, Universidade Federal do Paraná, Curitiba, Brasil, \\ Vinicius.emmel.m.92@gmail.com,luciene@ufpr.br \\ ${ }^{b}$ Centro de Ciências Exatas e Tecnologia, Faculdade de Engenharia Civil, Universidade Federal de Uberlândia, Uberlândia, \\ Brasil, marcioarschmidt@gmail.com
}

\begin{abstract}
:
Usability assessment performed by experts is a commonly used method to find interaction problems. In this research, a methodology that adapted different usability heuristics proposing the use of this method to carry out a usability assessment of a responsive web map accessed by different devices. Thus, it is proposed to develop and improve usability evaluation techniques to evaluate maps accessed through different devices.
\end{abstract}

Keywords: Heuristics, Digital Maps, Usability

The maps currently distributed on the web are indispensable tools for solving everyday geographic tasks and, therefore, usability research can guarantee the verification of the effectiveness of the interface's functionalities. Digital maps are currently considered one of the most interesting and challenging aspects for cartography (SILVA and GOMES, 2013; MONTELLO et al., 2018; SKOPELITI and STAMOU, 2019). Users access mobile maps to perform numerous tasks in their daily routines, however they often end up facing problems when interacting with applications or websites (GRIFFIN, et al., 2017). Specifically, when the interaction is performed on devices that are touch sensitive and devices with reduced screen size (MENDONÇA, 2013).

Considering the diversity of available devices, the concept of Mobile First emerged, for which the initial focus of system architecture and development is directed to mobile devices, to later be adapted to other platforms, such as the desktop (PHILIPP, 2016; JORENTE et al., 2019). Ideally, the interface fully responds to the project and facilitates communication with the user. In this context, usability tests using heuristics are essential to fulfill the purpose of evaluating the usability of a responsive web map.

The classic usability heuristics proposed by Nielsen (1993) are highly recognized and are the basis for many recent research on which this study is based (KOMARKOVA et al., 2011; KUPARINEN et al., 2013; WANGENHEIM et al., 2013; KOMARKOVA et al., 2017; KARAMPANAH, 2019; KOMARKOVA et al., 2019; HARLEY et al., 2019; BARTLING et al., 2019). Based on these studies, selections and adaptations of usability heuristics were carried out, which aimed to meet the necessary demands for the inspection of cartographic interfaces accessed by different devices, contributing to the adaptation of usability assessments, especially when the interface is not developed to following the Mobile First concept.

This article presents the evaluation of the WebGIS UFPR CampusMap (UCM) (www.campusmap.ufpr.br). This WebGIS was developed for the desktop environment through a responsive template, which can be accessed on mobile devices. A questionnaire was used, carried out remotely on a virtual platform. The selected heuristics for usability inspection for evaluating digital maps were defined based on the functionalities of the tested interface, as follows: "Accessibility to the map"; "Layer Activation"; "Identification and location of features, enlargement and reduction of scale"; "Researches"; "Find coordinates"; "Graphic scale"; "Routes"; "Measurement of distances between points"; "Area measurement; "Login and Data Download"; "Help in the description and use of cartographic tools"; "Textual elements of the map"; "System status visibility"; "Correspondence between the system and the real world"; "User control and freedom"; "Consistency and standards"; "Flexibility and efficiency of use"; "Aesthetics and design"; "Readability and layout"; "Physical interaction and ergonomics".

The interface was evaluated by 6 GIS experts divided into two groups, the first with desktops and the other using mobile devices. The results obtained through heuristics suggest that both devices obtained significant amounts of positive responses, demonstrating that the interface tested is functional. However, some functions were categorized differently according to the access device, showing that tests performed with a desktop device present a greater number of negative responses compared to responses obtained using the mobile device.

One of the advantages of the proposed methodology is that all tests were performed remotely and without the use of special equipment. The protocol developed used free videoconference platforms and forms and the participants performed the assessment asynchronously. In addition to the choice of heuristics, its application had the participation of users unfamiliar with usability engineering, requiring the use of some simplified terminology. We conclude that it was possible 
to gather a set of heuristics and carry out the inspection of a cartographic interface, using different devices to access and interact with the functionalities and their resources.

\section{Acknowledgements}

To the Coordination for the Improvement of Higher Education Personnel (CAPES) for encouraging research and financial support provided for in the notice (16/2018-PPGCG and Resolution 32/17-CEPE). To the CNPq for the financial support (Process 310312/2017-5).

\section{References}

BARTLING, M.; RESCH, B.; EITZINGER, A.; ZURITAARTHOS, L. A Multi National Human Computer Interaction Evaluation of the Public Participatory GIS GeoCitizen. GI_Forum 2019, v.7, p.19-39, 2019.

GRIFFIN, A. L.; ROBINSON, A. C.; ROTH, R. E. Envisioning the future of cartographic research. International Journal of Cartography, p.1-8, 2017.

HARLEY, J. M.; LIU, Y.; AHN, T. B.; LAJOIE, S. P.; GRACE, A. P.; HALDANE, C.; MCLAUGHLIN, B. I've got this: Fostering topic and technology-related emotional engagement and queer history knowledge with a mobile app. Contemporary Educational Psychology, v.59, 2019.

JORENTE, M. J. V.; PADUA, M. C.; NAKANO, N. O Design da Informação como recurso interdisciplinar da curadoria digital em contextos complexos da Ciência da Informação. Perspectivas em Ciência da Informação, v. 24, n. 3, p. 35-58, 2019.

KARAMPANAH, S. A survey of usability issues in mobile map-based systems. Master of Science in Geospatial Technologies Institute for Geoinformatics (ifgi) University of Münster. 2019.

KOMARKOVA, J.; SEDLAK, P.; HABRMAN, J.; CERMAKOVA, I. Usability evaluation of web-based gis by means of a model. In 2017 International Conference on Information and Digital Technologies (IDT), p.191-197, 2017.

KOMARKOVA, J.; SEDLAK, P.; NOVAK, M.; MUSILOVA, A.; SLAVIKOVA, V. Methods of usability evaluation of Web-based geographic information systems. International Journal of Systems Applications, Engineering \& Development, v.5, p.33-41, 2011.

KOMARKOVA, J.; SEDLAK, P.; STRUSKA, S.; DYMAKOVA, A. Usability Evaluation the Prague Geoportal: Comparison of Methods. In 2019 International Conference on Information and Digital Technologies (IDT), p.223-228, 2019.

KUPARINEN, L.; SILVENNOINEN, J.; ISOMÄKI, H. Introducing usability heuristics for mobile map applications. In: Proceedings of the 26th International Cartographic Conference, August 25 30, 2013, Dresden, Germany, ISBN 978-1-907075-06-3. International Cartographic Association, 2013.

MENDONÇA, A. L. A. Avaliação de interfaces cartográficas para dispositivos com tela sensível ao multitoque. Tese de doutoramento. Universidade Federal do Paraná, Programa de Pós-Graduação em Ciências Geodésicas, Curitiba, 2013.

MONTELlO, D. R.; FABRIKANT, S. I.; DAVIES, C. Cognitive perspectives on cartography and other geographic information visualizations. In: Handbook of behavioral and cognitive geography. Edward Elgar Publishing, p. 177-196, 2018.

NIELSEN, J. Usability Engineering. 1993.

PHILIPP. Why 'mobile first' is the new 'responsive'. Disponível em: http: //metamonks.com/mobilefirst-vsresponsive/. Acesso em: 20 de julho de 2020.

SILVA, L. F. F. C.; GOMES, J. V. P. O uso de Realidade Aumentada no desenvolvimento de produtos cartográficos. Revista Militar de Ciência e Tecnologia. Rio de Janeiro, 2013.

SKOPELITI, A.; STAMOU, L. Online Map Services: Contemporary Cartography or a New Cartographic Culture? ISPRS International Journal of Geo-Information, v.8, n.5, p.215, 2019.

WANGENHEIM, C. G. V.; BORGATTO, A.; WITT, A. T.; KRONE, C. MATcH Checklist formulário que serve de apoio à avaliação heurística. 2013. Disponível em: < http://match.inf.ufsc.br:90/ >. Acesso em: 03, dezembro de 2020 . 